\title{
PENGELOLAAN PERIKANAN TONGKOL LISONG (Auxis rochei) DI KAWASAN KONSERVASI PERAIRAN NUSA PENIDA, BALI
}

\section{FISHERIES MANAGEMENT OF BULLET TUNA (Auxis rochei) IN MARINE PROTECTED AREA OF NUSA PENIDA, BALI}

\author{
Ernik Yuliana ${ }^{1,2^{*}}$, Nurhasanah ${ }^{3}$, Diarsi Eka Yani $^{1}$, \& Siska Agustina ${ }^{4}$ \\ ${ }^{1}$ Program Studi Agribisnis, Fakultas Sains dan Teknologi, \\ Universitas Terbuka, Tangerang Selatan, 15418, Indonesia \\ ${ }^{2}$ Program Studi Magister Manajemen Perikanan, Program Pascasarjana \\ Universitas Terbuka, Tangerang Selatan 15418, Indonesia \\ ${ }^{3}$ Program Studi Magister Studi Lingkungan, Program Pascasarjana \\ Universitas Terbuka, Tangerang Selatan 15418, Indonesia \\ ${ }^{4}$ Wildlife Conservation Society (WCS) Indonesia Marine Program, Bogor, 16128, Indonesia \\ *E-mail: ernik@ecampus.ut.ac.id
}

\begin{abstract}
Nusa Penida is a marine protected area that has a high diversity of fish. Fishing of target fish is need to be properly regulated and managed to avoid overfishing. The aim of the study was to assess the management of bullet tuna (Auxis rochei) fishing in Nusa Penida using the EAFM indicators. The research conducted in Nusa Penida, Bali Province, on July-December 2018. Primary data collected includes ecological data (fish length and weight, and water quality) by survey to fish catches and waters; and socio-institutional data collected by distributing questionnaires to 54 respondents (drift nets, gill nets, hand line), and interviews with stakeholders. Data analysis was carried out descriptively. The results indicated that the bullet tunas had an average length of $24.59 \mathrm{~cm}$ with range of $21-34 \mathrm{~cm}$, smaller than the size range recorded in the fishbase of $35-50 \mathrm{~cm}$. The spawning potential ratio value is $23 \%$, which indicates overfished. Water quality is in accordance with seawater quality standards for marine biota. The implementation of traditional wisdom, namely Nyepi Segara, is adhered to by the local community. Assessment of bullet tuna management using EAFM indicators concluded that in the fish resources domain there were indications of overfished. Habitat domain (water quality and coral cover) is good. On the social aspect, the results are good, except that the respondent's income (54\%) is less than IDR 1,500,000.00.
\end{abstract}

Keywords: Auxis rochei, EAFM, fisheries, marine protected area, Nusa Penida

\begin{abstract}
ABSTRAK
Nusa Penida adalah kawasan konservasi perairan (KKp) yang memiliki keragaman jenis ikan yang tinggi. Penangkapan ikan target oleh nelayan perlu diatur dan dikelola dengan baik untuk menghindari tangkap lebih. Tujuan penelitian adalah menilai pengelolaan perikanan ikan tongkol lisong (Auxis rochei) yang sudah diterapkan di Nusa Penida menggunakan indikator Ecosystem Approach for Fisheries Management (EAFM). Penelitian dilakukan di perairan Nusa Penida, Provinsi Bali, pada Juli-Desember 2018. Pengumpulan data meliputi data ekologi (panjang dan bobot ikan, serta kualitas air) melalui survei terhadap hasil tangkapan dan perairan; data sosial-kelembagaan melalui kuesioner kepada 54 responden nelayan (jaring hanyut, jaring insang, pancing) dan wawancara dengan para pemangku kepentingan. Analisis data dilakukan secara deskriptif sesuai dengan domain dan indikator pada EAFM. Hasil penelitian menunjukkan bahwa ikan tongkol lisong mempunyai panjang rata-rata $24,59 \mathrm{~cm}$ dengan kisaran panjang (21-34) cm, lebih kecil daripada yang tercatat pada FishBase yaitu $35-50 \mathrm{~cm}$. Nilai spawning potential ratio adalah 23\% yang mengindikasikan overfished. Kualitas air sesuai dengan baku mutu perairan untuk biota laut. Penerapan kearifan tradisional yaitu Nyepi Segara ditaati oleh masyarakat lokal sebagai upaya untuk menjaga kelestarian sumber daya ikan (SDI). Penilaian pengelolaan perikanan tongkol lisong menggunakan indikator EAFM menyimpulkan bahwa pada domain SDI terjadi indikasi overfished. Domain habitat (kualitas air dan tutupan karang) dalam kondisi baik. Domain sosial dan ekonomi dalam kondisi baik, kecuali pendapatan responden (54\%) kurang dari Rp1.500.000,00.
\end{abstract}

Kata kunci: EAFM, kawasan konservasi perairan, Nusa Penida, perikanan, tongkol lisong 


\section{PENDAHULUAN}

Perairan Nusa Penida berada di wilayah Provinsi Bali yang terkenal dengan daya tarik wisatanya dan mempunyai nilai biodiversitas yang tinggi (Darma et al., 2010). Penetapan perairan Nusa Penida sebagai KKp didasarkan pada Peraturan Menteri Kelautan dan Perikanan No. 24/ Kepmen-KP/2014, yang bertujuan melestarikan sumber daya alam (SDA) dan meningkatkan produksi perikanan serta pendapatan nelayan (Bennett \& Dearden, 2014). Nusa Penida adalah salah satu KKp di Indonesia dengan luas 20.057 ha (Ruchimat et al., 2013). Awalnya, otoritas pengelola KKp Nusa Penida adalah Pemerintah Daerah Kabupaten Klungkung, tetapi sejak ada UU No. 23 Tahun 2014 otoritas pengelola adalah Pemerintah Daerah Provinsi Bali. KKp merupakan salah satu alat pengelolaan sumber daya laut untuk mencegah stok SDI habis (Wiadnya et al., 2011), dan juga merupakan alat penting untuk konservasi terumbu karang global (Allen et al., 2011). Nelayan lokal diharapkan mendapat manfaat dari KKp, yaitu meningkatkan hasil tangkapan dan menjaga kelestarian SDI dan habitat, dengan mengatur dan mengelola SDA (Ulloa et al., 2013). Sebagai salah satu tujuan wisata di Bali, Nusa Penida harus dapat mempertahankan keutuhan terumbu karang di perairan yang akan berpengaruh pada biodiversitas ikan. Aktivitas wisata bahari akan berpengaruh terhadap kesehatan terumbu karang (Jubaedah \& Anas, 2019).

Nusa Penida mempunyai jenis ikan pelagis dan ikan karang (576 spesies) (Allen \& Erdman, 2008), meliputi ikan target dan ikan hias. Jumlah spesies tersebut perlu dijaga kelestariannya dengan mengelola aktivitas penangkapan. Selama ini, penangkapan ikan target dilakukan oleh nelayan tradisional sebagai mata pencaharian utama (selain budi daya rumput laut dan wisata bahari), dengan menggunakan alat tangkap tradisional (jaring, pancing, dan panah). Armada penangkapan yang digunakan juga kapal tradisional $<5$ GT, sehingga nelayan tradisional tidak dapat menjangkau perairan yang jauh. Ikan yang dominan ditangkap oleh nelayan adalah ikan tongkol (Sanjaya, 2017) khususnya ikan tongkol lisong (Auxis rochei). Ikan tongkol sebagai target utama penangkapan di Nusa Penida adalah hal yang mengkhawatirkan, karena SDI perlu waktu untuk memulihkan diri setelah penangkapan. Ketika menjadi target utama penangkapan, maka tidak akan cukup waktu untuk memulihkan diri.

Pengelolaan perikanan yang sudah dilaksanakan di Nusa Penida adalah pengelolaan yang belum mengintegrasikan aspek ekologi, ekonomi, dan sosial. Hal tersebut berdampak pada beberapa kegiatan di perairan Nusa Penida yang tidak sinergi. Salah satu contohnya adalah kegiatan pariwisata bahari yang berdampak pada penurunan luasan tutupan karang keras sebesar 4,0\% (Jubaedah \& Anas, 2019). Ancaman kerusakan terhadap keanekaragaman hayati juga terjadi akibat praktik penangkapan ikan yang merusak, pembuangan jangkar di atas terumbu karang, serta pembuangan limbah ke laut (Darma et al., 2010). Semua ancaman dan dampak dari suatu kegiatan terhadap kegiatan lain harus dihindari sehingga memerlukan pengelolaan yang dapat mensinergikan beberapa kegiatan di perairan Nusa Penida.

Sinergitas antara kegiatan pariwisata dan perikanan perlu mendapat perhatian. Menjaga keberlanjutan SDI dan ekosistem, aktivitas penangkapan ikan memerlukan pengaturan dan pengelolaan yang baik (Cochrane et al., 2011; Pomeroy et al., 2010). Pengelolaan perikanan utamanya adalah proses mengelola manusia sebagai pengguna SDA, selain mengelola SDI (Widodo \& Suadi, 2006), yang meliputi aspek ekologi, sosial, ekonomi, dan komponen abiotik (Caddy, 1999; Garcia \& Cochrane, 2005). Terdapat beberapa pendekatan pengelolaan perikanan yang dapat diadopsi untuk pengelolaan perikanan di Nusa Penida. Salah satunya adalah pen- 
dekatan yang dikenalkan oleh Food and Agricultural Organization (FAO) pada tahun 2001, yaitu ecosystem approach to fisheries (EAF) (FAO, 2005), yang bertujuan mencapai keseimbangan antara tujuan ekonomi dan ekologi (Garcia \& Cochrane, 2005). EAF juga memperhatikan kegiatan lain di perairan selain perikanan agar terjadi sinergitas dan saling mendukung.

EAF digunakan oleh Kementerian Kelautan dan Perikanan (KKP) sebagai salah satu pilihan pendekatan pengelolaan perikanan dengan pendekatan ekosistem (EAFM). Indikator EAFM sudah dikembangkan oleh KKP dan diterapkan di beberapa perairan (Adrianto et al., 2013), namun penerapannya di KKp belum banyak dilakukan. Penerapan EAFM pada KKp memerlukan beberapa penyesuaian. KKp mempunyai aturan yang lebih ketat dalam penangkapan ikan dibandingkan dengan perairan biasa. EAFM membutuhkan diagnosis terhadap pengelolaan perikanan yang sudah ada (aktual) (Adrianto, 2013) untuk menentukan langkah taktis penyempurnaan pengelolaan perikanan (Gavaris, 2009).
Penelitian ini secara umum bertujuan menganalisis pengelolaan perikanan tongkol lisong (A. rochei) di perairan Nusa Penida sebagai KKp menggunakan indikator EAFM. Tujuan khusus penelitian adalah: 1) menganalisis kondisi aktual pengelolaan perikanan Nusa Penida menggunakan indikator EAFM; 2) Mengidentifikasi dan menganalisis indikator pengelolaan yang tidak sesuai dengan standar; 3) merumuskan rekomendasi kebijakan pengelolaan perikanan. Indikator EAFM sebelumnya telah disusun berdasarkan kondisi di Taman Nasional Karimunjawa (TNKJ) dengan mengadopsi indikator dari KKP dengan beberapa penyesuaian untuk KKp (Yuliana et al., 2019a).

\section{METODE PENELITIAN}

\subsection{Lokasi Penelitian}

Lokasi penelitian adalah perairan di sekitar Pulau Nusa Penida, Provinsi Bali dengan mengambil 5 (lima) titik pengambilan data kualitas air (Figure 1). Waktu penelitian adalah Juli-Desember 2018.

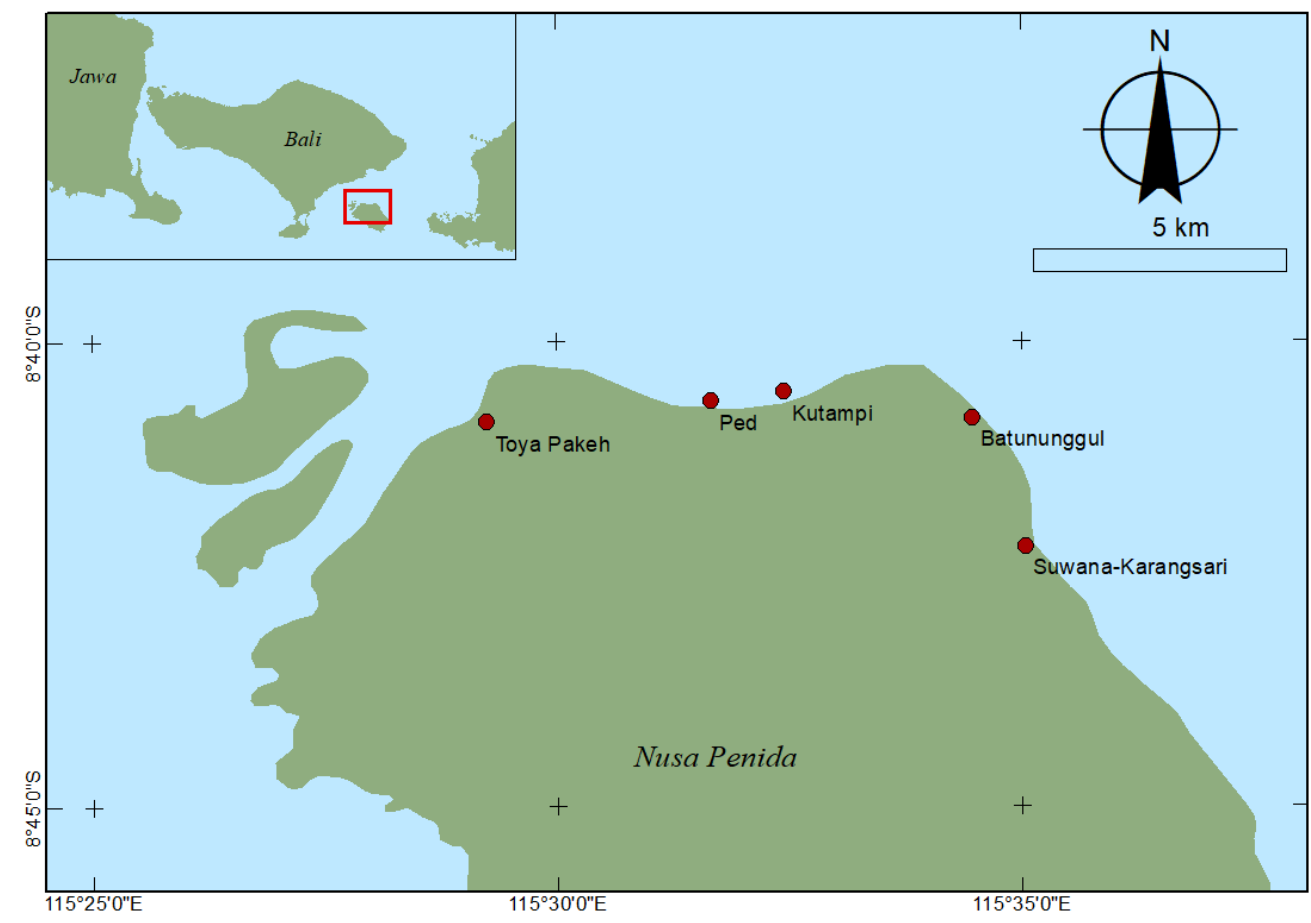

Figure 1. Study site and the location of collecting water quality data. 


\subsection{Pengambilan Data}

Pengambilan data menggunakan metode survei dan observasi. Indikator dan sumber data pada pengambilan data disajikan pada Table 1. Indikator EAFM yang digunakan mengalami penyesuaian didasarkan pada kondisi lapangan.

Pengambilan data kualitas air pada domain habitat dilakukan di lima lokasi penelitian (Table 2). Lima lokasi tersebut dianggap mewakili kondisi perairan Nusa Penida, karena kondisinya relatif homogen. Pengambilan data kualitas air bertujuan untuk memastikan kondisi perairan sesuai dengan baku mutu perairan untuk biota laut (Kepmen Negara Lingkungan Hidup No. 51 Tahun 2004).

Pengambilan data sosial, kelembagaan, dan ekonomi dilakukan dengan menye- barkan kuesioner kepada 54 responden nelayan tradisional yang berasal dari empat desa (Table 3) dan wawancara dengan para pemangku kepentingan. Kondisi nelayan di Nusa Penida relatif homogen, sehingga jumlah responden (54 orang) dianggap representatif.

\subsection{Analisis Data}

Analisis data dilakukan secara deskriptif pada beberapa aspek pengelolaan berdasarkan indikator EAFM. Analisis data ukuran ikan yang tertangkap menggunakan pengelompokan ukuran ikan berdasarkan panjang ikan.

Pendugaan mortalitas alami (M) dilakukan menggunakan software FISAT II dengan metode Pauly's $M$ Equation dan mortalitas total $(\mathrm{Z})$ dengan metode length

Table 1. Data collection indicators.

\begin{tabular}{|c|c|c|}
\hline EAFM Domains & Indicators & Data Sources \\
\hline \multirow[t]{3}{*}{ Fish resources } & Size of the fish caught & Fishermen catches \\
\hline & Exploitation rate & Fish length \\
\hline & Spawning potential ratio $(S P R)$ & Fish length \\
\hline \multirow[t]{3}{*}{ Habitat } & Turbidity & Total dissolved solid (TDS) \\
\hline & Water quality & pH and temperature \\
\hline & Coral cover & $\%$ coral cover \\
\hline \multicolumn{3}{|l|}{ technology } \\
\hline Institutional & $\begin{array}{l}\text { Fishermen's knowledge of the } \\
\text { principles of responsible fishing }\end{array}$ & Fishermen's perception \\
\hline \multirow[t]{2}{*}{ Social } & $\begin{array}{l}\text { Fishermen's knowledge about fish } \\
\text { resources sustainability }\end{array}$ & Fishermen's perception \\
\hline & Utilization of local knowledge & Traditional wisdom \\
\hline Economic & Fishermen's income & Fishermen's income \\
\hline
\end{tabular}

Source: Yuliana et al. (2019a) with modifications.

Table 2. Location of water quality data collection.

\begin{tabular}{lcc}
\hline \multirow{2}{*}{ Location } & \multicolumn{2}{c}{ Coordinate Point } \\
\cline { 2 - 3 } & South & East \\
\hline Batununggul (green beach inn) & $8^{\circ} 40^{\prime} 50^{\prime \prime}$ & $115^{\circ} 34^{\prime} 29^{\prime \prime}$ \\
Toya Pakeh & $8^{\circ} 40^{\prime} 52^{\prime \prime}$ & $115^{\circ} 29^{\prime} 15^{\prime \prime}$ \\
Suwana (Karangsari) & $8^{\circ} 42^{\prime} 13^{\prime \prime}$ & $115^{\circ} 35^{\prime} 3^{\prime \prime}$ \\
Ped & $8^{\circ} 40^{\prime} 39^{\prime \prime}$ & $115^{\circ} 31^{\prime} 40^{\prime}$ \\
Kutampi & $8^{\circ} 40^{\prime} 33^{\prime \prime}$ & $115^{\circ} 32^{\prime} 27^{\prime}$, \\
\hline
\end{tabular}


Table 3. Respondents' age.

\begin{tabular}{lcccccc}
\hline \multicolumn{7}{c}{ Respondents'Village } \\
\hline $\begin{array}{l}\text { Age Interval of } \\
\text { Respondents }\end{array}$ & $\begin{array}{c}\text { Karang } \\
\text { Sari } \\
\text { (Suana) }\end{array}$ & Kutampi & $\begin{array}{c}\text { Batumulapan } \\
\text { (Batununggul) }\end{array}$ & Batununggul & Total & $\%$ \\
\hline 17-30 years & 0 & 1 & 0 & 0 & 1 & 2 \\
$31-50$ years & 16 & 2 & 9 & 3 & 30 & 55 \\
$51-60$ years & 13 & 0 & 7 & 1 & 21 & 39 \\
$>60$ years & 1 & 0 & 1 & 0 & 2 & 4 \\
\hline Total & 30 & 3 & 17 & 4 & 54 & 100 \\
\hline
\end{tabular}

converted-catch curve (Pauly, 1984; Gayanilo et al., 2006). Setelah nilai Z dan M diketahui maka laju mortalitas penangkapan (F) dapat ditentukan melalui hubungan $\mathrm{F}=$ Z-M. Laju eksploitasi ditentukan dengan formula:

$E=\frac{F}{z}$

Keterangan: $E=$ laju eksploitasi; $F=$ mortalitas penangkapan; $Z=$ mortalitas total.

Penghitungan SPR menggunakan formula yang pernah digunakan oleh Yuliana et al. (2019b).

SSB $=\sum_{t=t_{m}}^{t_{\lambda}} N_{t} x W_{t}$

Keterangan: $W_{t}$ merupakan bobot dan $N_{t}$ adalah jumlah individu ikan. SPR ditentukan dari kematian ikan akibat penangkapan $(F)$ yang berbeda, dengan formula sebagai berikut:

$$
S P R=\frac{S S B_{F}}{S S B_{F=0}}
$$

Keterangan: $S S B_{F}$ adalah biomassa ikan yang dieksploitasi; dan $S S B_{F=0}$ adalah biomassa ikan pada kondisi asli (tidak ada penangkapan). Hasil penghitungan SPR berkisar antara 0-100\%. Ault et al. (2008) menjelaskan bahwa SPR standar adalah 30\%, jika ikan mempunyai nilai SPR <30\% maka indikasinya adalah ikan tersebut mengalami tangkap lebih.

Analisis data kualitas air dilakukan di Laboratorium Produktivitas dan Lingkungan
Perairan, Departeman Sumberdaya Perairan, IPB University. Hasil analisis dibandingkan dengan nilai baku mutu perairan untuk biota laut; data sosial dan kelembagaan dianalisis dengan confirmatory factor analysis (CFA).

\section{HASIL DAN PEMBAHASAN}

\subsection{Sumber Daya Ikan \\ 3.1.1. Ukuran Ikan}

Ikan yang dominan ditemukan pada waktu penelitian adalah tongkol lisong ( $A$. rochei) dengan ukuran panjang ikan disajikan pada Table 4, ikan lain ditemukan dalam jumlah yang sedikit, yaitu ikan kulit pasir dan ikan cendro. Selanjutnya, analisis SDI difokuskan pada ikan tongkol lisong, karena jumlahnya yang dominan. Nelayan menangkap ikan sepanjang tahun menggunakan alat tangkap tradisional (utamanya jaring insang). Libur melaut hanya dilakukan pada saat Nyepi Segara.

Ikan tongkol lisong yang ditemukan mempunyai panjang rata-rata $24,59 \mathrm{~cm}$ dengan panjang minimum $21 \mathrm{~cm}$ dan maksimum $34 \mathrm{~cm}$, data lengkap disajikan pada Table 4. Ukuran tersebut lebih kecil daripada ukuran rata-rata yang tercatat pada FishBase (fishbase.org) yaitu $35-50 \mathrm{~cm}$. Ukuran ikan yang paling banyak ditemukan adalah 23,8 cm-25, $1 \mathrm{~cm}$ (Table 5).

\subsubsection{Laju Eksploitasi}

Berdasarkan data panjang ikan, didapatkan beberapa parameter populasi dan nilai laju eksploitasi (Table 6). Laju eksploi- 
tasi yang diperoleh dari penghitungan berdasarkan mortalitas ikan adalah 0,69. Berdasarkan kriteria Pauly (1984), nilai laju eksploitasi (E) yang rasional dan lestari di suatu perairan berada pada nilai $\mathrm{E}<0,5$ atau maksimum nilai $\mathrm{E}=0,5$. Dengan demikian, laju eksploitasi ikan tongkol lisong terindi- kasi adanya tangkap lebih (overfishing).

\subsubsection{Spawning Potential Ratio (SPR)}

SPR adalah ukuran yang menunjukkan potensi kemampuan ikan untuk memijah. Nilai SPR ikan tongkol lisong di perairan Nusa Penida adalah 23\%, menunjuk-

Table 4. Group size of bullet tuna caught.

\begin{tabular}{lcc}
\hline \multirow{2}{*}{ Data Collection Time in 2018 } & \multicolumn{2}{c}{ Bullet Tuna } \\
\cline { 2 - 3 } & Number of samples (individual) & Average length $(\mathrm{cm})$ \\
\hline August & 33 & 25.55 \\
September & 70 & 26.76 \\
October & 155 & 23.96 \\
November & 170 & 24.46 \\
December & 80 & 24.19 \\
\hline Total & 508 & - \\
\hline
\end{tabular}

Table 5. Data of fish length and their frequency.

\begin{tabular}{cc}
\hline Fish Length $(\mathrm{cm})$ & Frequency \\
\hline $21.0-22.3$ & 41 \\
$22.4-23.7$ & 155 \\
$23.8-25.1$ & 170 \\
$25.2-26.5$ & 65 \\
$26.6-27.9$ & 40 \\
$28.0-29.3$ & 15 \\
$29.4-30.7$ & 6 \\
$30.8-32.1$ & 14 \\
$32.2-33.5$ & 0 \\
$33.6-34.9$ & 2 \\
\hline Total & 508 \\
\hline
\end{tabular}

Table 6. Growth parameters and mortality.

\begin{tabular}{lc}
\hline \multicolumn{1}{c}{ Pupulation Parameters } & Value \\
\hline Growth: & \\
Growth coefficient $(\mathrm{k})$ & 0.51 per year \\
The theoretical age when fish length & -0.16 year \\
equals to zero $\left(\mathrm{t}_{0}\right)$ & \\
Infinity fish length $\left(\mathrm{L}_{\infty}\right)$ & $35.29 \mathrm{~cm}$ \\
Fish length when first caught $\left(\mathrm{L}_{\mathrm{c}}\right)$ & $23.94 \mathrm{~cm}$ \\
Mortality: & \\
Natural mortality $(\mathrm{M})$ & 0.48 per year \\
Fishing mortality $(\mathrm{F})$ & 1.08 per year \\
Total mortalty $(\mathrm{Z})$ & 1.55 per year \\
Exploitation rate $(\mathrm{E})$ & 0.69 \\
\hline
\end{tabular}


kan bahwa kapasitas ikan dewasa yang siap memijah di alam sedikit, sehingga dapat diartikan stok ikan tongkol lisong dalam kondisi overfished (Ault et al., 2008). Kondisi ini mengkhawatirkan, sehingga perlu adanya upaya dari otoritas pengelola dan masyarakat nelayan untuk mengendalikan penangkapan ikan tongkol lisong. Penyuluhan yang intensif kepada masyarakat tentang keberlanjutan SDI diperlukan untuk mengurangi overfished, salah satunya adalah pembatasan upaya penangkapan dan pengaturan ukuran mata jaring. Upaya tersebut dilakukan agar ukuran pertama kali ikan tertangkap $\left(\mathrm{L}_{\mathrm{c}}\right)$ meningkat, dengan demikian nilai SPR juga akan meningkat (Yuliana et $a l .$, 2019b). Setelah penyuluhan, perlu dilakukan pengawasan untuk membangun kesadaran nelayan dalam pembatasan upaya penangkapan. Pengawasan dapat dilakukan secara kolaboratif antara otoritas pengelola KKp dan masyarakat (Rees et al., 2013).

\subsection{Habitat}

\subsubsection{Kekeruhan Perairan}

Kekeruhan perairan pada penelitian ini menggunakan indikator total dissolved solid (TDS), yaitu jumlah padatan terlarut berupa komponen organik atau anorganik yang berukuran kurang dari $1 \mathrm{~nm}$ (Tanto et al., 2018). Nilai TDS adalah 4,02 ppm (Table 7), menunjukkan bahwa perairan Nusa Penida berada dalam kategori baik (jernih). Hal tersebut didasarkan pada standar yang ditetapkan oleh Environmental Protection Agency (EPA) Amerika Serikat bahwa nilai TDS yang ideal di suatu perairan adalah maksimum 50 ppm (Tanto et al., 2018).

Table 7. Data of TDS value.

\begin{tabular}{lc}
\hline \multicolumn{1}{c}{ Location } & $T D S(\mathrm{ppm})$ \\
\hline Batununggul & 3.41 \\
(green beach inn) & \\
Toya Pakeh & 3.78 \\
Suana (Karangsari) & 3.72 \\
Ped & 4.09 \\
Kutampi & 5.10 \\
\hline Average & 4.02 \\
\hline
\end{tabular}

\subsubsection{Kualitas Air}

Kualitas air merupakan indikator penting dalam pengelolaan perikanan, karena akan memengaruhi kehidupan ikan dan organisme lainnya. Kualitas air juga sangat berpengaruh pada pertumbuhan karang dan rekrutmen karang. Nilai $\mathrm{pH}$ mempunyai rata-rata 8,12 , dan nilai suhu rata-rata adalah $27,01^{\circ} \mathrm{C}$ (Table 8). Kedua parameter kualitas air tersebut sesuai dengan Baku Mutu Perairan untuk Biota Laut, yaitu $\mathrm{pH}$ antara 7-8,5 dan suhu alami (Kepmen Negara Lingkungan Hidup No. 51 Tahun 2004).

\subsubsection{Tutupan Karang}

Persentase tutupan karang pada tahun 2017 adalah 67,28\% (Sanjaya, 2017) berada dalam kategori baik (Sanjaya, 2017), begitu juga menurut Jubaedah \& Anas (2019) bahwa luasan tutupan karang berkisar 52\%-97\% (kategori baik), meskipun ada penurunan $4 \%$ akibat kegiatan pariwisata bahari. Menurut data Coral Triangle Center (CTC), persentase tutupan karang di perairan Nusa Penida berada dalam kondisi

Table 8. Results of water quality measurement.

\begin{tabular}{lcc}
\hline \multicolumn{1}{c}{ Location } & $p H$ & Temperature $\left({ }^{\circ} \mathrm{C}\right)$ \\
\hline Batununggul (green beach inn) & 8.03 & 27.07 \\
Toya Pakeh & 8.13 & 26.17 \\
Suana (Karangsari) & 8.00 & 27.13 \\
Ped & 8.27 & 26.93 \\
Kutampi & 8.17 & 27.47 \\
\hline Average & 8.12 & 26.95 \\
\hline
\end{tabular}


bagus dari tahun 2011-2016. Bahkan pada tahun 2015, kondisi tutupan karang berada dalam kondisi memuaskan, yaitu $84,5 \%$ (Sanjaya, 2017).

Kondisi tutupan karang yang baik berhubungan dengan kehidupan ikan karang, karena terumbu karang adalah habitat utama ikan karang untuk mencari makan, pengasuhan, dan perlindungan. Selain itu tutupan karang yang baik juga akan menarik wisatawan untuk berkunjung ke Nusa Penida. Arus wisatawan ini harus dikendalikan oleh otoritas pengelola karena akan berdampak pada SDI.

\subsection{Teknologi Penangkapan Ikan}

Nelayan Nusa Penida yang menjadi responden penelitian semuanya menggunakan alat tangkap yang ramah lingkungan, diantaranya adalah jaring hanyut, jaring insang, dan pancing ulur. Sebagian besar responden $(98 \%)$ menyatakan bahwa alat tangkap yang digunakan tidak merusak terumbu karang (Table 9). Semuanya adalah jenis alat tangkap tradisional, sesuai dengan armada yang digunakan yaitu kapal tradesional $(<5$ GT). Akan tetapi, aktivitas perikanan yang merusak (bom dan racun, serta kegiatan tangkap lebih) masih menjadi ancaman utama di KKp Nusa Penida (Ruchimat et al., 2013).

Table 9. Respondents' answers to the statement "fishing gear can damage coral reefs".

\begin{tabular}{lcc}
\hline $\begin{array}{l}\text { Respondent } \\
\text { S'Answers }\end{array}$ & $\begin{array}{c}\text { Number of } \\
\text { Respondens } \\
\text { (person) }\end{array}$ & $\begin{array}{c}\text { Percentage } \\
(\%)\end{array}$ \\
\hline Strongly & 23 & 43 \\
Disagree & 25 & 45 \\
Disagree & 2 & 4 \\
Abstain & 2 & 4 \\
Agree & 2 & 4 \\
Strongly & 54 & 100 \\
Agree & & \\
\hline Total & & \\
\hline
\end{tabular}

\subsection{Kelembagaan}

Sebagai salah satu destinasi wisata di Provinsi Bali, perairan Nusa Penida menerima kunjungan wisatawan yang cukup signifikan. Perlu dilakukan sinkronisasi antara kegiatan pariwisata dan perikanan agar terjadi sinergitas dan tidak saling merugikan. Perairan Nusa Penida sudah dibagi menjadi beberapa zona sesuai dengan peruntukan masing-masing yang dituangkan dalam Keputusan Menteri Kelautan dan Perikanan No. 24/Kepmen-KP/2014. Beragamnya pemanfaatan perairan laut Nusa Penida mengharuskan para pemangku kepentingan terutama nelayan memahami prinsip-prinsip perikanan bertanggung jawab.

Pada penelitian ini pengetahuan nelayan tentang prinsip perikanan bertanggung jawab diukur melalui kuesioner (Table 10). Jawaban kuesioner dianalisis menggunakan CFA (Figure 2).

Berdasarkan hasil uji-t pada analisis CFA yang disajikan pada Figure 2, dari enam pernyataan pada kuesioner, ada empat butir pernyataan yang signifikan untuk mengukur pengetahuan nelayan. Keempat pernyataan ini selanjutnya dapat digunakan untuk mengukur pengetahuan nelayan tentang prinsip perikanan bertanggung jawab. Berdasarkan jawaban pada kuesioner, responden yang mempunyai pengetahuan yang baik untuk keempat pernyataan adalah: 1) $\mathrm{C} 13=93 \%$; 2) $\mathrm{C} 14=98 \%$; 3) $\mathrm{C} 15=87 \%$; 4) $\mathrm{C} 16=98 \%$. Dengan demikian, pengetahuan nelayan tentang prinsip perikanan bertanggung jawab dalam kategori baik.

\subsection{Sosial \\ 3.5.1. Persepsi Nelayan tentang SDI}

Jumlah nelayan (rumah tangga perikanan/RTP) di Kecamatan Nusa Penida adalah 498 RTP (Darma et al., 2010). Persepsi nelayan tentang kelestarian SDI dan habitat diukur melalui kuesioner (Table 11). Jawaban kuesioner dianalisis menggunakan CFA (Figure 3).

Berdasarkan hasil uji-t pada analisis CFA (Figure 3), dari 11 pernyataan pada 
Table 10. Questionnaire statement about fishermen's knowledge of the principles of responsible fisheries.

\begin{tabular}{lc}
\hline \multicolumn{1}{c}{ Statements } & Codes \\
\hline Fishermen must be responsible for the health of the aquatic environment & $\mathrm{C} 11$ \\
The responsibility of fishermen is proven by complying with the rules & $\mathrm{C} 12$ \\
Fishing rules come from the government and fishermen's agreement & $\mathrm{C} 13$ \\
There is a fishing gear regulation & $\mathrm{C} 14$ \\
Fishing gear only for adult fish & $\mathrm{C} 15$ \\
There is a prohibition on the use of destructive fishing gear & $\mathrm{C} 16$ \\
\hline
\end{tabular}

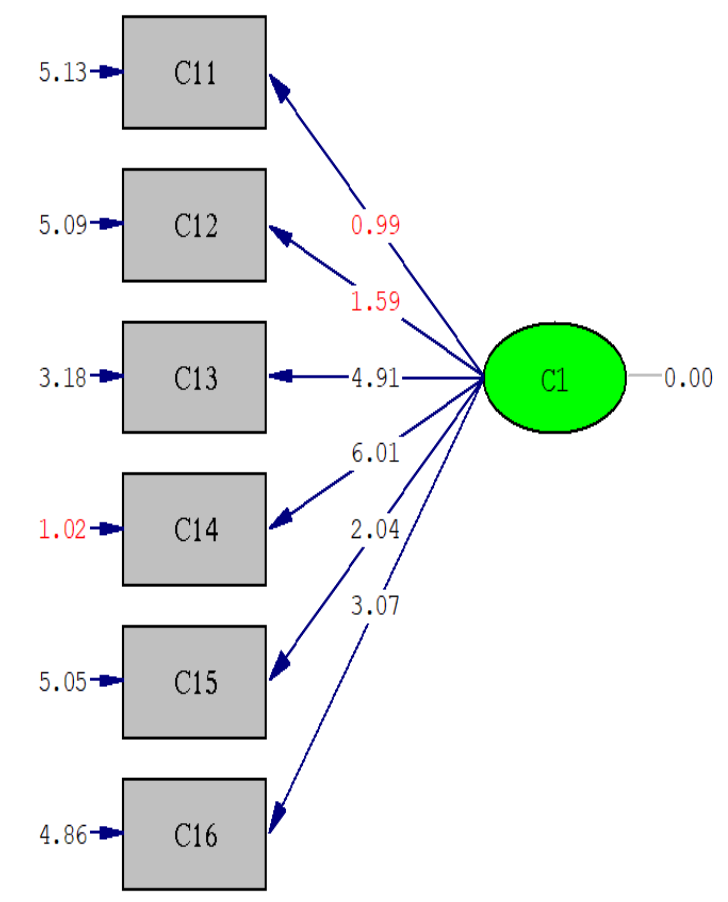

Chi-Square $=19.59, \mathrm{df}=9$,

P-value $=0.02063$, RMSEA $=0.149$

Figure 2. The results of the t-test of respondents' perceptions of the principles of responsible fisheries with CFA.

kuesioner, ada tujuh butir pernyataan yang signifikan untuk mengukur persepsi nelayan. Ketujuh pernyataan ini selanjutnya dapat digunakan untuk mengukur persepsi nelayan tentang SDI dan habitat. Berdasarkan jawaban pada kuesioner, responden yang mempunyai jawaban setuju dan sangat setuju pada ketujuh pernyataan adalah; 1) $\mathrm{A} 11=59 \%$; 2) $\mathrm{A} 12=77 \%$; 3) $\mathrm{A} 14=96 \%$; 4) $\mathrm{A} 15=20 \%$; 5) $\mathrm{A} 17=96 \%$; 6) $\mathrm{A} 18=24 \%$; $)$

A110 $=8 \%$. Sebagian besar responden berpendapat bahwa ukuran ikan yang tertangkap semakin kecil dan jumlahnya semakin menurun, dan alat tangkap yang digunakan tidak merusak terumbu karang. Persepsi nelayan tersebut sejalan dengan hasil penelitian Karta (2014) bahwa hasil tangkapan

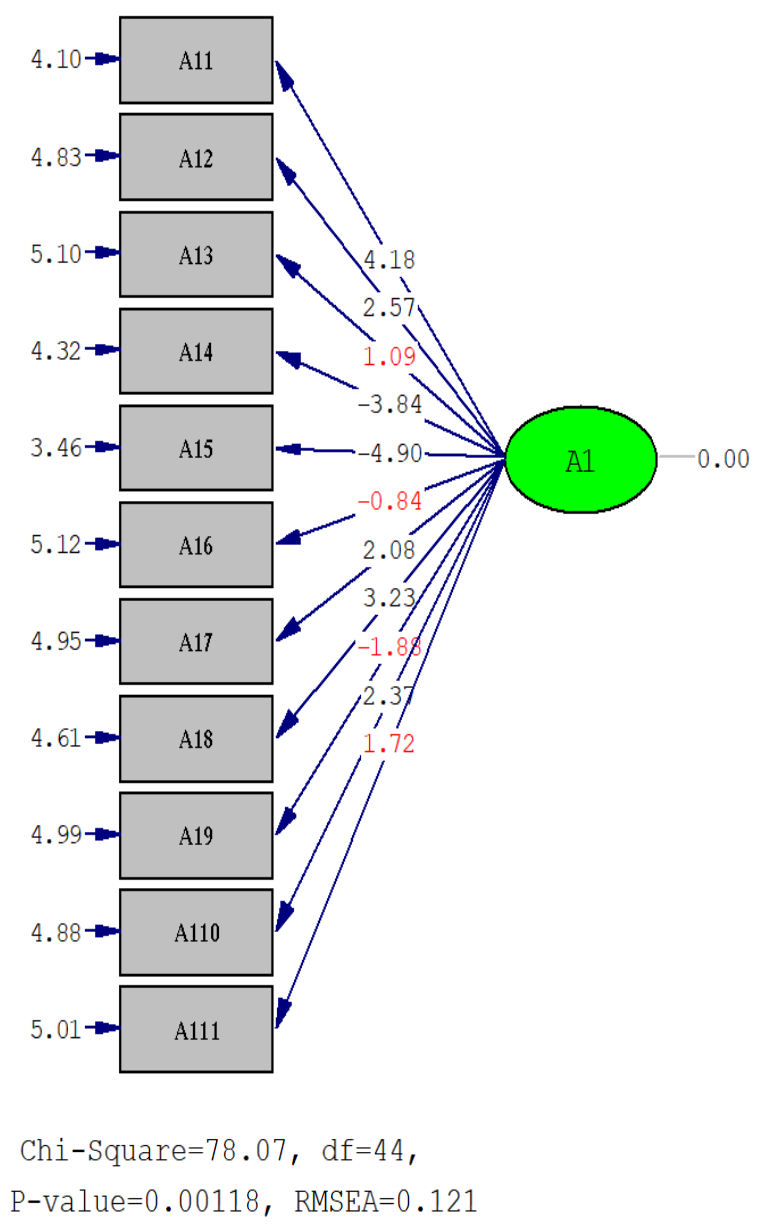

Figure 3. The results of the t-test of respondents' perceptions of fish resources and coral reefs. 
Table 11. Questionnaire statements regarding fishermen's perceptions of fish resources and coral reefs.

\begin{tabular}{lc}
\hline \multicolumn{1}{c}{ Statements } & Codes \\
\hline The size of the fish caught is getting smaller & $\mathrm{A} 11$ \\
The number of fish caught is decreasing & $\mathrm{A} 12$ \\
The fishing area is getting further away & $\mathrm{A} 13$ \\
Fish must be saved in order to be sustainable & $\mathrm{A} 14$ \\
There are protected fish species & $\mathrm{A} 15$ \\
There is a ban on fishing that is protected & $\mathrm{A} 16$ \\
Coral reefs need to be preserved & $\mathrm{A} 17$ \\
The coral reef area in Nusa Penida is decreasing & $\mathrm{A} 18$ \\
Maintaining of coral reefs is a must & $\mathrm{A} 19$ \\
The fishing gear that I use can damage coral reefs & $\mathrm{A} 110$ \\
There is a prohibition on catching immature fish & $\mathrm{A} 111$ \\
\hline
\end{tabular}

Source: Yuliana et al. (2016) with modification.

ikan di Nusa Penida menurun sejak tahun 2005. Temuan pada domain SDI pada penelitian ini juga menunjukkan gejala overfished, sesuai dengan ukuran ikan yang tertangkap semakin kecil. Dengan demikian, persepsi nelayan tentang SDI secara umum baik, berbeda dengan hasil penelitian Winata \& Yuliana (2010) dan Yuliana et al. (2016) bahwa tingkat persepsi nelayan tentang konservasi SDI umumnya adalah rendah.

\subsubsection{Pemanfaatan Kearifan Lokal}

Nelayan Nusa Penida mempunyai pemahaman yang didasari oleh pengetahuan dan kearifan lokal, selain pengetahuan dari otoritas pengelola kawasan konservasi. Kearifan lokal yang diterapkan di Nusa Penida salah satunya adalah Nyepi Segara. Pelaksanaan Nyepi Segara yang jatuh pada Purnama sasih kapat atau purnama keempat berdasarkan penanggalan Bali (Adnyani et al., 2014) yaitu seluruh aktivitas laut dihentikan atau tidak melakukan penangkapan ikan dalam sehari, yang biasanya dilaksanakan pada September-Oktober (Darma et al., 2010; Adnyani et al., 2014). Kearifan lokal tersebut memengaruhi persepsi nelayan tentang SDI. Nyepi Segara juga berlaku bagi aktivitas transportasi laut dari dan menuju Pulau Nusa Penida, termasuk pariwisata di kawasan Pulau Nusa (Adnyani et al., 2014).

\subsection{Ekonomi}

Berdasarkan hasil survei, responden mempunyai pendapatan minimal Rp200.000,00 per bulan dan maksimal Rp2.000.000,00 per bulan. Nelayan yang menjadi responden penelitian sebagian besar $(46,00 \%)$ mempunyai pendapatan lebih dari Rp1.500.000,00 (Table 12). Sebelumnya, nelayan mendapatkan tambahan pendapatan dari budi daya rumput laut (Sanjaya, 2017, Ruchimat et al., 2013), namun pada saat survei dilakukan, budi daya rumput laut sedang mengalami kerugian, sehingga pendapatan nelayan hanya dari hasil tangkapan ikan.

Table 12. Group of fishremens' income.

\begin{tabular}{lcc}
\hline \multicolumn{1}{c}{ Income Group per Month } & Amounth & Percentage (\%) \\
\hline Less than IDR $1,000,000$ & 8 & 15.00 \\
Between IDR $1,000,000-$ IDR $1,500,000$ & 21 & 39.00 \\
More than IDR $1,500,000$ & 25 & 46.00 \\
\hline \multicolumn{1}{c}{ Total } & 54 & 100.00 \\
\hline
\end{tabular}




\subsection{Rekomendasi Kebijakan}

Berdasarkan hasil penilaian kondisi aktual pengelolaan perikanan di Nusa Penida, ada beberapa indikator yang memerlukan langkah taktis untuk memperbaiki pe- ngelolaan perikanan (Gavaris, 2009). Langkah taktis tersebut merupakan rekomendasi kebijakan bagi otoritas pengelola KKp Nusa Penida (Table 13).

Table 13. Tactical decision for fisheries management in Nusa Penida.

\begin{tabular}{|c|c|c|}
\hline $\begin{array}{l}\text { Domains and Indicators } \\
\text { of EAFM }\end{array}$ & Actual Conditions & $\begin{array}{c}\text { Tactical Decisions for Policy } \\
\text { Recommendations }\end{array}$ \\
\hline \multicolumn{3}{|l|}{ Fish resources: } \\
\hline Size of the fish caught & $\begin{array}{l}\text { Fish length (21-34) cm with } \\
\text { fish length avarage } 24.59 \mathrm{~cm} \text {. } \\
\text { Smaller than the fish length in } \\
\text { FishBase }(35-50) \mathrm{cm}\end{array}$ & $\begin{array}{l}\text { 1. Educate fishers to build } \\
\text { their awareness for } \\
\text { catching adult fish } \\
\text { 2. Regulate fishing effort so }\end{array}$ \\
\hline Exploitation rate $(E)$ & $E=0.69$ (overfishing) & that the mesh size of nets \\
\hline $\begin{array}{l}\text { Spawning potential ratio } \\
\text { (SPR) } \\
\text { Habitat: }\end{array}$ & SPR 23\% (overfishing) & $\begin{array}{l}\text { 3. Increase the fishing } \\
\text { monitoring }\end{array}$ \\
\hline $\begin{array}{l}\text { Habitat: } \\
\text { Turbidity (TDS) }\end{array}$ & $\begin{array}{l}T D S=4.02 \mathrm{ppm} \text { reach } E P A \\
\text { standard }(50 \mathrm{ppm})\end{array}$ & $\begin{array}{l}\text { Maintain water quality } \\
\text { conditions }\end{array}$ \\
\hline Water quality & $\begin{array}{l}p H=8.12 \text { and temperature }= \\
27.01^{\circ} \mathrm{C} \text { (reach Water Quality } \\
\text { Standards for marine biota) }\end{array}$ & \\
\hline Coral cover & $\begin{array}{l}52 \%-97 \% \text { (good category), } \\
\text { there was } 4 \% \text { decrease due to } \\
\text { marine tourism }\end{array}$ & $\begin{array}{l}\text { Educate tourists to be more } \\
\text { careful not to damage corals }\end{array}$ \\
\hline \multicolumn{3}{|l|}{ Fishing Technology: } \\
\hline $\begin{array}{l}\text { Environmental friendly } \\
\text { fishing }\end{array}$ & $\begin{array}{l}\text { The fishing gear used by } \\
\text { fishermen were drift nets, gill } \\
\text { nets, hand lines }\end{array}$ & $\begin{array}{l}\text { Maintain the use of } \\
\text { environmentally friendly } \\
\text { fishing gear }\end{array}$ \\
\hline \multicolumn{3}{|l|}{ Institutional: } \\
\hline $\begin{array}{l}\text { Fishermen's knowledge } \\
\text { of the principles of } \\
\text { responsible fishing }\end{array}$ & $\begin{array}{l}\text { In general, it was good } \\
\text { category, but there were } 13 \% \\
\text { of respondents who did not } \\
\text { realize that fishing gear should } \\
\text { be used for adult fish }\end{array}$ & $\begin{array}{l}\text { Educate fishers to build their } \\
\text { awareness for catching adult } \\
\text { fish }\end{array}$ \\
\hline \multicolumn{3}{|l|}{ Social: } \\
\hline $\begin{array}{l}\text { Fishermen's knowledge } \\
\text { about fish resources } \\
\text { sustainability }\end{array}$ & $\begin{array}{l}\text { The fish size caught was } \\
\text { getting smaller and the } \\
\text { numbers were decreasing }\end{array}$ & $\begin{array}{l}\text { 1. Educate fishers about } \\
\text { sustainable fish resources } \\
\text { 2. Monitor to fish caugth }\end{array}$ \\
\hline $\begin{array}{l}\text { Utilization of local } \\
\text { knowledge }\end{array}$ & $\begin{array}{l}\text { Nyepi Segara: not doing } \\
\text { activities in the sea, to honor } \\
\text { the god of the sea }\end{array}$ & $\begin{array}{l}\text { Maintain the use of local } \\
\text { wisdom of Nyepi Segara }\end{array}$ \\
\hline \multicolumn{3}{|l|}{ Economic: } \\
\hline Fishermen's income & $\begin{array}{l}46 \% \text { of respondents have an } \\
\text { income }>\text { IDR } 1,500,000.00\end{array}$ & $\begin{array}{l}\text { Maintain fishermen's income } \\
\text { level }\end{array}$ \\
\hline
\end{tabular}




\section{KESIMPULAN}

Penilaian pengelolaan perikanan tongkol lisong pada kondisi aktual menghasilkan beberapa temuan penting, yaitu: 1) Terjadi overfishing pada sumber daya ikan tongkol lisong dengan nilai laju eksploitasi 0,69 dan SPR 23\%; 2) Kualitas air (TDS, $\mathrm{pH}$, dan suhu) sesuai dengan baku mutu perairan untuk biota laut (Kepmen Negara Lingkungan Hidup No. 51 Tahun 2004); 3) Tutupan karang dalam kondisi baik (52\%97\%); 4) Pengetahuan nelayan tentang pengelolaan perikanan perlu ditingkatkan karena beberapa responden belum menyadari pentingnya kelestarian SDI.

Beberapa indikator tidak sesuai dengan standar, terutama dalam domain SDI, yaitu laju eksploitasi yang seharusnya maksimum 0,50 dan nilai SPR minimum $30 \%$. Beberapa langkah taktis diusulkan sebagai rekomendasi untuk kebijakan pengelolaan perikanan di Nusa penida, diantaranya adalah: 1) memberikan penyuluhan kepada nelayan untuk menangkap ikan dewasa, kelestarian sumber daya ikan; 2) mengatur upaya penangkapan ikan dan ukuran mata jaring; 3) meningkatkan pengawasan terhadap penangkapan ikan.

\section{UCAPAN TERIMA KASIH}

Penulis mengucapkan terima kasih kepada LPPM Universitas Terbuka yang telah membiayai penelitian melalui skema Penelitian Terapan; KKP yang berkantor di Nusa Penida dan UPT Dinas Ketahanan Pangan, Peternakan, dan Perikanan Kecamatan Nusa Penida yang telah memberikan izin penelitian dan menyediakan data sekunder, serta Coral Triangle Center Sanur, Bali yang telah memberikan data sekunder.

\section{DAFTAR PUSTAKA}

Adrianto, L. 2013. Konsep dan aplikasi teori tata kelola sumber daya (resource governance) dalam pengelolaan ekosistem terumbu karang. Dalam: Nikijuluw et al. (ed.). Coral governance. IPB Press. Bogor. 21-60 pp.

Adrianto, L., T. Ruchimat, \& A. Habibi. 2016. Building in integrated reference indicators and knowledge management system for implementation of EAFM in Indonesia. National Working Group Ecosystem Approach to Fisheries Management, Ministry of Marine Affairs and Fisheries, Republic of Indonesia. 30 p.

Adnyani, N.K.S., I.N.D. Prasetia, \& R.A. Windari. 2014. Nyepi Segara sebagai kearifan lokal masyarakat Nusa Penida dalam pelestarian lingkungan laut. J. Ilmu Sosial dan Humaniora, 3(1): 300-312.

https://doi.org/10.23887/jishundiksha.v3i1.2921

Allen, G.R. \& M.V. Erdman. 2008. Reef fish of Nusa Penida, Indonesia. Final Report to Conservation International. $22 \mathrm{p}$.

Allen, H.V., S. Mourato, \& E.J.M. Gulland. 2011. A global evaluation of coral reef management performance: Are MPAs producing conservation and socio-economic improvements? Environmental Management, 47: 684-700. https://doi.org/10.1007/s00267-0119616-5

Ault, J., S.G. Smith, M.E. Monaco, \& R.S. Appeldoorn. 2008. Length-based aassessment of sustainability benchmarks for coral reef fishes in Puerto Rico. Environmental Conservation, 35(3): 221-231. https://doi.org/10.1017/S0376892908 005043

Bennett, N.J. \& P. Dearden. 2014. Why local people do not support conservation: Community perceptions of marine protected area 
livelihood impacts, governance and management in Thailand. Marine Policy, 44: 107-116. https://doi.org/10.1016/j.marpol.2013 .08 .017

Caddy, J.F. 1999. Fisheries management in twenty-first century: will new paradigms apply?. Reviews in Fish Biology and Fisheries, 9: 1-43. https://doi.org/10.1023/A:100882990 9601

Cochrane, K., D. Gréboval, R. Pomeroy, J.S. Sanders, M. Sissenwine, \& L. Wstlund. 2011. Fisheries Management. Marine protected areas and fisheries. Dalam: FAO technical guidelines for responsible fisheries. FAO. Rome. 198 p.

Darma, N., R. Basuki, \& M. Welly. 2010. Profil kawasan konservasi perairan (KKp) Nusa Penida Kabupaten Klungkung, Provinsi Bali. Pemda Klungkung, Kementerian Kelautan dan Perikanan, The Nature Conservancy. Klungkung. 76 p.

Food and Agricultural Organization (FAO). 2005. Putting into practice the ecosystem approach to Fisheries. FAO. Rome. 76 p.

Garcia, S.M. \& K.L. Cochrane. 2005. Ecosystem approach to fisheries: A Review of implementation guidelines. ICES J. of Marine Sciences, 62: 311-318.

https://doi.org/10.1016/j.icesjms.200 4.12.003

Gayanilo, Jr.F.C., P. Sparre, \& D. Pauly. 2006. FAO-ICLARM stock assessment tools (FiSAT II). Revised version. User's guide. Food and Agriculture Organization of the United Nations, Rome. 168 p.

Gavaris, S. 2009. Fisheries management planning and support for strategic and tactical decisions in an ecosystem approach context. Fisheries Research, 100: 6-14. https://doi.org/10.1016/j.fishres.2008
.12 .001

Jubaedah, I. \& P. Anas. 2019. Dampak pariwisata bahari terhadap ekosistem terumbu karang di Perairan Nusa Penida, Bali. J. Penyuluhan Perikanan dan Kelautan, 13(1): 5975.

https://doi.org/10.33378/jppik.v13i1. 124

Karta, I.W. 2014. Teknologi reef ball melalui pemberdayaan Sekehe Teruna-Teruni (STT) dalam upaya konservasi terumbu karang di kawasan konservasi perairan (KKp) Nusa Penida. Prosiding Seminar Nasional FMIPA Undhiksa IV. 354$359 \mathrm{pp}$.

Kepmen Kelautan dan Perikanan No. 24/Kepmen-KP/2014 tentang Kawasan Konservasi Perairan Nusa Penida Kabupaten Klungkung di Provinsi Bali. 5 p.

Kepmen Negara Lingkungan Hidup No. 51 Tahun 2004 tentang Baku Mutu Perairan Laut untuk Biota Laut. 6 p.

Pauly, D. 1984. Some simple methods for tropical fish stock. FAO Fish. Tech. Pap. 243. 52 p.

Pomeroy, R., L. Garces, M. Pido, \& G. Silvestre. 2010. Ecosystem-based fisheries management in small scale tropical marine fisheries: Emerging models governance arrangements in the Philippines. Marine Policy, 34: 298-308.

https://doi.org/10.1016/j.marpol.2009 .07 .008

Rees, S.E., L.D. Rodwell, S. Searle, \& A. Bell. 2013. Identifying the issues and options for managing the social impacts of Marine Protected Areas on a small fishing community. Fisheries Research, 146: 51-58. https://doi.org/10.1016/j.fishres.2013 .04 .003

Ruchimat, T., R. Basuki, \& M. Welly. 2013. Nusa Penida marine protected area (Mpa) Bali - Indonesia: Why need to 
be protected? Transylvanian Review of Systematical and Ecological Research, 15(1): 193-202. https://doi.org/10.2478/trser-20130016

Sanjaya, W. 2017. Laporan monitoring kesehatan terumbu karang di Kawasan Konservasi Perairan Nusa Penida. CTC. Sanur, Bali. 20 p.

Tanto, T.A., N. Naelul, \& I. Ilham. 2018. Kualitas air laut untuk mendukung wisata bahari dan kehidupan biota laut (Studi Kasus: Sekitar Kapal Tenggelam Sophie Rickmers, Perairan Prialaot Sabang). $J$. Kelautan: Indonesian J. of Marine Science and Technology, 11(2): 173183. https://doi.org/10.21107/jk.v11i2.427 6

Ulloa, R., A. Vargas, C. Hudson, \& M.M. Rivadeneira. 2013. Zoning of the Mejillones Peninsula marine protected coastal area of multiple uses, northern Chile. Latin American J. of Aquatic Research, 41(3): 506-518. https://doi.org/10.3856/vol41-issue3fulltext-14

Wiadnya, D.G.R., R. Syafaat, E. Susilo, D. Setyohadi, Z. Arifin, \& B. Wiryawan. 2011. Recent development of marine protected areas (MPAs) in Indonesia: Policies and governance. J. of Applied Environmental and Biological Sciences, 1(12): 608-613. https://www.textroad.com/JAEBSDecember,\%202011.html

Widodo, J. \& Suadi. 2006. Pengelolaan sumber daya perikanan laut. Gajah Mada University Press. Yogyakarta. $252 \mathrm{p}$.
Winata, A. \& E. Yuliana. 2010. Peran masyarakat pesisir dalam penerapan strategi konservasi sumberdaya laut (Kasus di Kelurahan Palabuhanratu, Kecamatan Palabuhanratu, Kabupaten Sukabumi). $J$. Matematika, Sains, \& Teknologi 11(2): 122-132. https://jurnal.ut.ac.id/index.php/jmst/ article/view/573

Yuliana, E., A. Fahrudin, M. Boer, M.M. Kamal, \& S.T. Pardede. 2016. The effectiveness of the zoning system in the management of reef fisheries in the marine protected area of Karimunjawa National Park, Indonesia. AACL Bioflux, 9(3): 483497.

http://www.bioflux.com.ro/docs/201 6.483-497.pdf

Yuliana, E., M. Boer, A. Fahrudin, \& S.T. Pardede. 2019a. Using ecosystem approach indicators for assessing the ecological status of reef fisheries management in a marine protected area. Biodiversitas, 20(7): 18021810.

https://doi.org/10.13057/biodiv/d200 703

Yuliana, E., Nurhasanah, \& I. Farida. 2019b. Analisis keberlanjutan sumber daya ikan karang Famili Caesionidae di Kawasan Konservasi Taman Nasional Karimunjawa. $J$. Matematika, Sains, \& Teknologi, 20(1): 57-67. https://doi.org/10.33830/jmst.v20i1.9 6.2019

Received : 30 August 2020

Reviewed : 23 September 2020

Accepted : 29 November 2020 